\title{
GAYA BAHASA PERBANDINGAN DALAM KUMPULAN PUISI ADA BERITA APA HARI INI, DEN SASTRO? KARYA SAPARDI DJOKO DAMONO (TINJAUAN STILISTIKA)
}

\author{
Wa Ode Isdalisa, ${ }^{1}$ La Ode Balawa, ${ }^{2}$ La Ode Syukur ${ }^{3}$ \\ pbsi.fkip.uho@gmail.com \\ 1,2,3, Jurusan Pendidikan Bahasa dan Sastra Indonesia, \\ Fakultas Keguruan dan Ilmu Pendidikan, Universitas Halu Oleo \\ Kampus Hijau Bumi Tridharma Anduonohu, Kendari, Indonesia
}

\begin{abstract}
Abstrak
Tujuan dari penelitian ini adalah untuk mendeskripsikan gaya bahasa perbandingan dalam kumpulan puisi Ada Berita Apa Hari ini, Den Sastro? karya Sapardi Djoko Damono dan peran gaya bahasa perbandingan dalam kumpulan puisi Ada Berita Apa Hari ini, Den Sastro? karya Sapardi Djoko Damono. Metode yang digunakan dalam penelitian ini adalah metode deskriptif kualitatif. Jenis penelitian yang digunakan dalam penelitian ini adalah penelitian kepustakaan. Data yang digunakan dalam penelitian ini adalah data tertulis berupa teks puisi, yang memuat gaya bahasa perbandingan dalam kumpulan puisi Ada Berita Apa Hari ini, Den Sastro? karya Sapardi Djoko Damono. Sumber data dalam penelitian ini adalah sumber data tertulis dalam kumpulan puisi Ada Berita Apa Hari Ini, Den Sastro? karya Sapardi Djoko Damono yang diterbitkan oleh PT Gramedia Pustaka Utama, Jakarta, cetakan pertama pada Maret 2017, cetakan kedua pada Mei 2017, dan terdiri atas 12 puisi. Teknik pengumpulan data yang digunakan dalam penelitian ini adalah teknik baca dan teknik catat. Pendekatan Stilistika digunakan untuk mendeskripsikan gaya bahasa perbandingan yang terdapat dalam kumpulan puisi Ada Berita Apa Hari Ini, Den Sastro? karya Sapardi Djoko Damono. Berdasarkan hasil penelitian dan pembahasan, dapat disimpulkan bahwa gaya bahasa perbandingan yang terdapat dalam kumpulan puisi Ada Berita Apa Hari Ini, Den Sastro? karya Sapardi Djoko Damono ada 6 jenis gaya bahasa perbandingan yaitu gaya bahasa Personifikasi, Asosiasi atau Perumpamaan, Metafora, Simbolik, Simile dan Antropomorfisme. Gaya bahasa perbandingan sangat berperan penting dalam kumpulan puisi Ada Berita Apa Hari Ini, Den Sastro? karya Sapardi Djoko Damono karena dengan menggunakan gaya bahasa atau bahasa kiasan maka puisi tersebut mempunyai sisi keindahan sehingga sajak dalam puisi tersebut menarik untuk di baca.
\end{abstract}

Kata Kunci: gaya Bahasa; perbandingan; puisi 


\section{PENDAHULUAN \\ 1.1 Latar Belakang}

Selama ini, puisi masih mendapat tempat terhormat dalam setiap budaya yang menjunjung tinggi karya sastra. Puisi banyak digemari oleh semua lapisan masyarakat dan dianggap sebagai hiburan yang mempunyai arti kehidupan bagi pembacanya karena mempunyai banyak kata-kata kiasan.

Sepanjang zaman, puisi selalu mengalami perubahan dan perkembangan. Puisi selalu berubah-ubah sesuai dengan evolusi selera dan perubahan konsep estetiknya menurut Riffaterre (dalam Pradopo 2017: 3). Menurut Coleridge dalam Pradopo (2017: 6) puisi merupakan katakata yang terindah dalam susunan terindah. Dalam puisi, kata-kata tidaklah keluar dari simpanan ingatan, tetapi kata-kata dalam puisi lahir dan dilahirkan kembali (dibentuk) pada waktu pengucapannya sendiri. Dalam puisi tak ada perbedaan kata dengan pikiran. Pikiran itu kata sendiri dan kata itu pikiran sendiri (kata dan pikiran itu adalah puisi).

Menurut Haryanta (2012: 78) gaya bahasa merupakan cara khas dalam menyatakan pikiran dan perasaan dalam bentuk tulis atau lisan. Gaya bahasa adalah bagaimana seorang penulis berkata mengenai apapun yang dikatakannya menurut Abrams (dalam Pradopo 2017: 272). Penggunaan gaya bahasa terutama dalam puisi memang mempengaruhi gaya dan keindahan bahasa. Dengan menggunakan gaya bahasa, maka seringkali mempunyai arti tambahan dari sekedar arti yang ada. Mengkaji gaya bahasa memungkinkan dapat menilai pribadi, karakter, dan kemampuan pengarang yang menggunakan bahasa itu sendiri. Gaya bahasa terdiri dari gaya bahasa perbandingan, pertentangan, penegasan, dan sindiran.

Gaya bahasa perbandingan adalah bahasa yang menyamakan sesuatu hal dengan mempergunakan kata pembanding seperti: bagai, bak, seperti, laksana, umpama, ibarat, dan lain-lain. Gaya bahasa ini sudah dimanfaatkan sejak lama, karena relatif sederhana dan banyak digunakan dalam karya sastra khususnya puisi.

Setiap pengarang mempunyai gaya bahasa yang berbeda-beda dalam mengungkapkan ide atau gagasan kedalam tulisannya. Semua puisi yang di tulis oleh pengarang tidak bisa dilepaskan dari penggunaan gaya bahasa. Sebab, dari penggunaan gaya bahasa inilah puisi bisa terlihat memiliki arti khusus yang bukan dalam arti sebenarnya. Gaya bahasa dalam puisi bertujuan untuk mempengaruhi dan membawa pembaca hanyut dalam suasana hati tertentu seperti baik, dan buruk. Selain itu, gaya bahasa juga bertujuan untuk lebih memperindah kalimat yang terdapat pada puisi tersebut. Jadi, dengan menggunakan gaya bahasa, puisi yang di tulis oleh pengarang dapat terlihat lebih indah dan mampu menampilkan nilai estetika yang sangat tinggi.

Buku kumpulan puisi Ada Berita Apa Hari Ini, Den Sastro? adalah salah satu karya Sapardi Djoko Damono yang merupakan pensiunan Guru Besar UI. Puisi ini diterbitkan pada tahun 2017 oleh PT Gramedia Utama. Di dalam puisi ini terdapat 12 puisi yang mempunyai gaya bahasa yang khas.

Kumpulan puisi Ada Berita Apa Hari Ini, Den Sastro? karya Sapardi Djoko Damono merupakan puisi narasi atau puisi yang berbentuk cerita. Kalimat dalam puisi ini lebih panjang seperti membaca sebuah cerita pendek yang di sampaikan dengan bahasa puitis. Banyak kata-kata yang akan sulit ditafsirkan artinya sehingga pembaca merasa kesulitan untuk menangkap pesan yang disampaikan dan perlu berulang kali membacanya agar dapat di mengerti maksudnya. Selain itu, puisi ini juga kental dengan perenungan yang mendalam. Puisi ini menceritakan tentang kemarahan yang di tuliskan oleh penulisnya. Pengarang seperti ingin meluapkan segala kekesalan dan emosinya dalam puisi yang dia tulis.

Kumpulan puisi Ada Berita Apa Hari Ini, Den Sastro? karya Sapardi Djoko Damono, belum pernah dibahas dari segi gaya bahasa ataupun dari segi pendekatan sastra lainnya. Seperti contoh dalam potongan puisi Damono (2017: 3) "Sudah sejak lama cahaya pagi yang kaki-kakinya telanjang tidak pernah lagi menyapamu Selamat Pagi; ia hanya berjalan-jalan di depan rumahmu, tak di pahaminya timbunanan huruf itu". Puisi ini termasuk 
salah satu gaya bahasa perbandingan yaitu personifikasi. Gaya bahasa perbandingan sering digunakan pengarang dalam menulis puisi sebagai bahasa kiasan karena relatif sederhana. Gaya bahasa perbandingan selalu digunakan pengarang untuk membangun sajak dan memperindah sebuah puisi. Penelitian tentang gaya bahasa dalam puisi ini belum pernah dilakukan, untuk itu penelitian tentang gaya bahasa perlu dilakukan. Puisi ini dikaji menggunakan pendekatan stilistika.

Alasan penulis mengkaji puisi tersebut menggunakan pendekatan stilistika karena dalam penulisan puisi tidak akan lepas dari gaya bahasa. Setiap puisi memiliki gaya bahasa yang berbeda yang menarik untuk dikaji.

\subsection{Rumusan Masalah}

Berdasarkan uraian latar belakang yang telah dipaparkan maka yang menjadi masalah dalam penelitian ini adalah:

1. Gaya bahasa perbandingan apa saja yang terdapat dalam kumpulan puisi Ada Berita Apa Hari Ini, Den Sastro? karya Sapardi Djoko Damono?

2. Bagaimanakah peran gaya bahasa perbandingan dalam kumpulan puisi Ada Berita Apa Hari Ini, Den Sastro? 3. karya Sapardi Djoko Damono?

\subsection{Tujuan Penelitian}

Berdasarkan permasalahan di atas maka tujuan dari penelitian ini adalah:

1. Untuk mendeskripsikan gaya bahasa perbandingan dalam kumpulan puisi Ada Berita Apa Hari Ini, Den Sastro? karya Sapardi Djoko Damono?

2. Untuk mengetahui peran gaya bahasa perbandingan dalam kumpulan puisi Ada Berita Apa Hari Ini, Den Sastro? karya Sapardi Djoko Damono?

\subsection{Manfaat Penelitian}

Manfaat yang ingin dicapai dalam penelitian ini adalah sebagai berikut.

1. Sumbangan pemikiran dalam upaya meningkatkan mutu apresiasi terhadap karya sastra, khususnya mengenai gaya bahasa dalam puisi Indonesia modern.

2. Bahan masukan dalam pengembangan apresiasi sastra Indonesia baik dunia pendidikan pada khususnya maupun di kalangan masyarakat pada umumnya.
3. Sumbangan pemikiran tentang kajian gaya bahasa perbandingan dalam puisi bagi para peneliti yang relevan.

\section{KAJIAN PUSTAKA}

2.1 Pengertian Puisi

Kata puisi berasal dari bahasa Yunani, yaitu poesis yang berarti "membuat" atau "menciptakan". Puisi merupakan pernyataan perasaan yang imajinatif, yaitu perasaan yang direkakan. Perasaan dan pikiran penyair yang masih abstrak dikongkretkan. Untuk mengkonkretkan peristiwa-peristiwa yang telah direkam didalam pikiran dan perasaan penyair, puisi merupakan salah satu sarananya. Coleridge dalam Pradopo (2017: 6) puisi adalah kata-kata yang terindah dalam susunan terindah. Sedangkan menurut Atmanegara (2018: 163) puisi merupakan karya sastra dengan pilihan yang menonjol berupa pilihan kata dan tipografi.

Menurut Haryanta (2012: 2119) puisi merupakan ragam sastra yang bahasanya terikat oleh irama, mantra, rima serta penyusunan larik dan bait sedangkan prosa merupakan karangan bebas yang tidak terikat oleh kaidah yang terdapat dalam puisi. Oleh karena itu, tidak heran bila puisi juga banyak melahirkan sastrawansastrawan terkemuka, seperti Chairil Anwar, Sutadji Calzoum Bachri, W.S. Rendra, Ajib Rosidi, dan sebagainya.

\subsection{Unsur-unsur Puisi}

Unsur-unsur dalam puisi terdiri atas unsur intrinsik dan unsur ekstrinsik. Unsur intrinsik puisi antara lain unsur tema, unsur suasana (latar), unsur imaji, unsur simbol (lambang), unsur musikalitas puisi (nada atau bunyi), unsur gaya bahasa, dan unsur amanat. Sedangkan unsur ekstrinsik dalam puisi antara lain keadaan sosial penyair, lingkungan penyair, profesi penyair, pengalaman penyair, kondisi ekonomi penyair, dan peran penyair dalam masyarakat.

\subsection{Struktur Puisi} struktur yaitu:

Struktur dalam puisi terdiri atas dua

\subsubsection{Struktur Fisik Puisi}

Sebuah puisi, pasti memiliki struktur fisik atau unsur bentuknya. Menurut 
Mulyadi (2017: 149) struktur fisik puisi biasanya digunakan oleh penyair sebagai sarana untuk membangun puisi atau mengukapkan hakikat dalam puisi. Adapun struktur fisik puisi sebagai berikut:

1. Diksi

Diksi adalah kata-kata yang dipilih oleh penyair dalam puisinya yang dimaksud untuk menimbulkan imajinasi yang estetis.

2. Citraan / Imaji

Secara sederhana, citraan adalah penyerapan indera terhadap hal-hal yang diungkapkan dalam puisi.

3. Kata Konkret

Penggunaan kata konkret bertujuan untuk menimbulkan imajinasi pada pembaca.

4. Bahasa Figuratif

Bahasa figuratif adalah bahasa yang digunakan penyair untuk mengatakan sesuatu dengan cara menbandingkan suatu hal dengan hal yang lainnnya.

5. Versifikasi

Versifikasi merupakan unsur pembentuk keindahan sebuah puisi. Adapun versifikasi terdiri atas rima, rotma, dan metrum.

6. Tata Wajah (Tipografi)

Tipografi atau perwajahan puisi adalah bentuk puisi yang dikehendaki oleh penyair, misalnya penuh tidaknya katakata, rata tidaknya bagian tepi kanan kiri puisi, atau penagturan baris.

\subsubsection{Struktur Batin}

Struktur batin puisi adalah media untuk mengungkapkan makna yang hendak disampaikan penyair. Struktur batin puisi terdiri atas:

a. Tema

Dalam setiap puisi, terdapat inti permasalahan terdapat inti permasalahan yang ingin diungkapkan oleh penyair. Inti permasalahan yang hendak dikemukakan penyair itulah yang disebut dengan tema.

b. Rasa

Rasa adalah sikap penyair terhadap pokok permasalahan yang terdapat dalam puisinya.

c. Nada dan Suasana

Nada adalah sikap yang ditunjukan penyair terhadap pembaca dalam puisinya, misalnya menggurui dan menyindir. d. Amanat

Amanat adalah pesan yang ingin disampaikan oleh penyair melalui puisinya.

\subsection{Peranan Puisi}

Puisi memiliki peranan-peranan penting yang bermanfaaat bagi kehidupan manusia. Menurut Wahyuni, (2014: 27) peranan puisi digolongkan sebagai berikut:

1. Puisi dapat memberikan rasa senang, sejuk dan gembira bagi pembacanya.

2. Puisi mampu mendorong pembacanya untuk berpikir lebih dalam mengenai pesan yang terkandung di dalamnya.

3. Puisi dapat melatih imajinasi pendengarnya untuk membayangkan latar dari puisi yang sedang dibaca.

4. Puisi mampu mendorong pembacanya untuk mengintrospeksi diri jika di dalam puisi tersebut terkandung makna yang sekiranya dapat membuat pembaca teringat akan sesuatu yang sebenarnya tidak baik.

5. Puisi mampu mengarahkan dan mendidik pembacanya untuk menjalankan nilai-nilai kebenaran yang terkandung di dalamnya.

\section{5 Pengertian Gaya Bahasa}

Menurut Haryanta (2012: 78) gaya bahasa merupakan cara khas dalam menyatakan pikiran dan perasaan dalam bentuk tulis atau lisan. Tujuan utama gaya bahasa adalah menghadirkan aspek keindahan. Pada umumnya gaya bahasa dibedakan menjadi empat macam, yaitu:

a. Gaya Bahasa Penegasan

Gaya bahasa penegasan merupakan kata-kata kiasan yang menyatakan penegasan untuk meningkatkan kesan dan pengaruhnya terhadap pendengar ataupun pembaca.

b. Gaya Bahasa Perbandingan

Gaya bahasa perbandingan merupakan gaya bahasa yang menyamakan sesuatu hal dengan yang lain dengan mempergunakan kata pembanding seperti: bagai, bak, seperti, laksana, umpama, ibarat, dan lain-lain.

c. Gaya Bahasa Pertentangan

Gaya bahasa pertentangan merupakan gaya bahasa yang menggunakan kata-kata kiasan yang menunjukan suatu pertentangan atau keadaan yang berlawanan dengan kondisi sebenaranya. 
d. Gaya Bahasa Sindiran

Gaya bahasa sindiran merupakan gaya bahasa yang menggunakan kata kiasan untuk menyatakan sesuatu yang sebaliknya atau sebuah sindiran.

Dari berbagai pernyataan di atas dapat disimpulakan bahwa gaya bahasa adalah pilihan kata tertentu sesuai dengan maksud penulis atau pembicara dalam rangka memperoleh aspek keindahan.

\section{6 Pengertian Gaya Bahasa Perbandingan}

Gaya bahasa perbandingan adalah gaya bahasa yang menyamakan sesuatu hal dengan yang lain dengan mempergunakan kata pembanding seperti: bagai, bak, seperti, laksana, umpama, ibarat, dan lain-lain. Gaya bahasa ini sudah dimanfaatkan sejak lama, karena relatif sederhana.

\subsection{Jenis-Jenis Gaya Bahasa Perbandingan}

Ada beberapa jenis gaya bahasa perbandingan yaitu:

\section{Personifikasi}

Personifikasi adalah gaya bahasa yang menganggap benda-benda tidak bernyawa mempunyai kegiatan atau melakukan aktivitas tertentu seolah-olah hidup. Personifikasi adalah gaya bahasa yang menggambarkan benda-benda mati atau barang-barang yang tidak bernyawa seolah-olah memiliki sifat kemanusiaan Keraf (dalam Hasanuddin 2002: 135.

Contoh pada potongan puisi dibawah ini: Kaulah kandil kemerlap Pelita jendela dimalam gelap Melambai pulang perlahan Sabar, setia selalu

\section{Asosiasi atau Perumpamaan}

Menurut Masruchin (2017: 10) asosiasi adalah gaya bahasa yang membandingkan antara dua hal yang sebenarnya sangat berbeda, namun sengaja dianggap sama. Biasanya asosiasi atau perumpamaan dibubuhi kata bagai, bagaikan, seumpama, bak, seperti, dan laksana.

Contohnya seperti pada potongan puisi dibawah ini:

Di tengah sunyi menderu rinduku.
Seperti topan. Meranggutkan dahan, mencabutkan akar, meranggutkan kemabang kalbuku.

\section{Metafora}

Metafora adalah gaya bahasa yang memperbandingkan secara langsung sesuatu hal dengan hal lain yang memiliki sifat, keadaan, atau perbuatan yang sama. Metafora adalah gaya bahasa perbandingan yang tidak menggunakan kata seperti, bak, bagai, atau bagaikan, sehingga pokok pertama di hubungkan dengan pokok kedua menurut Keraf (dalam Hasanuddin 2002: 136).

Contoh:

Bumi ini perempuan jalang.

\section{Simbolik}

Simbolik adalah gaya bahasa yang menunjukan simbol atau menyamakan benda dengan nama benda lain. Simbolik adalah gaya bahasa yang menggambarkan sesuatu dengan menggunakan binatang, benda, dan tumbuh-tumbuhan sebagai simbol atau lambang.

Contoh :

Orang-orang di gedung DPR ramai memperebutkan kursi pemerintahan. (jabatan)

\section{Metonimia}

Bahasa kiasan yang lebih jarang dijumpai pemakaiannya dibanding metafora, perbandingan, dan personifikasi ialah metonimia dan sinekdok. Metonimia dalam bahasa Indonesia sering disebut kiasan pengganti nama. Bahasa ini berupa penggunaan sebuah atribut, sebuah objek atau penggunaan sesuatu yang sangat dekat berhubungan dengannnya untuk menggantikan objek tersebut menurut Alternberd (Pradopo, 2017: 78).

Contoh pada potongan puisi dibawah ini: Klakson dan loncemg bunyi bergiliran....... Dan perempuan mendaki tepi sun kesayangan

Di bawah bayangan samar istana kejang

$\mathrm{O}$, kota kekasih setelah senja

\section{Depersonifikasi}

Depersonifikasi adalah gaya bahc yang mengungkapkan benda hid.. menjadikan seperti benda mati atau tidak bernyawa.

Contoh:

Andai engkau jadi buku aku akan jadi penanya. 


\section{Eponim}

Eponim adalah gaya bahasa yang menjadikan nama orang sebagai tempat.

Contoh:

Gelora Bung Karno.

\section{Sinekdok}

Sinekdok terdiri atas dua bentuk yakni Pras Prototo dan Totem Pro Parte. Pars Pro toto adalah gaya bahasa yang menyebutkan sebagian benda untuk keseluruhan.

Contoh pada potongan puisi dibawah ini:

Terasa aneh dan aneh

Sepasang-sepasang mata

memandangku

Menimpakan dosa

Terus terderitakankan pandang begini

Totem Pro Parte, yaitu menyebutkan keseluruhan benda, namun untuk sebagian.

Contoh:

Kujelajahi bumi dan alis kekasih

Bumi itu totum pro parte, sedang alis kekasih itu pars pro toto.

\section{Simile}

Simile adalah gaya bahasa yang mengungkapkan perbandingan eksplesit yang dinyatakan dengan kata depan dan penghubung, seperti layaknya, "bagaikan, umpama, ibarat, bak, bagai”. Simile hampir sama dengan asosiasi.

Contoh:

Tubuhnya seperti tiang yang menjulang.

Wajahnya bercahaya bagaikan rembulan.

Dia pemberani bak seekor singa yang tidak pernah gentar dengan musuh sekuat apapun.

\section{Alegori}

Alegori adalah gaya bahasa yang menyatakan perihal dengan menggunakan kiasan atau penggambaran.

Contoh :

Ular yang mendesis merisik, dengan warna kulit indah

Mengejarku, bahkan sampai dalam mimpi.

Berhenti kataku. Dan ia menatap patuh, namun gelisah

Tiba-tiba kubaca: namamu terukir pada lidahnya

Yang terjalur merah.

\section{Sinestesia}

Sinestesia adalah gaya bahasa yang menghubungkan satu indra dengan indra lain.

Contoh:
Betapa sedap memandang gadis cantik yang bersolek.(Kata sedap untuk penciuman, tapi digunakan untuk penglihatan).

\section{Disfemisme}

Disfemisme adalah gaya bahasa yang mengungkapkan pernyataaan tabu atau yang dirasa kurang pantas sebagaimana adanya.

Contoh:

Bolehkah saya meminta izin untuk kencing sebentar? (Padahal, ia ingin ke WC).

\section{Eufimisme}

Eufimisme adalah gaya bahasa yang mengubah atau menggantikan kata yang dipandang kurang pantas dan kasar dengan kata yang lebih pantas.

Contoh:

Pemerintah sedang memberantas tunasusila

\section{Aptronim}

Aptronim adalah gaya bahasa ya memberi nama yang cocok dengan sifat at pekerjaan orang.

Contoh:

Karena ibunya penjual soto, ia seri dipanggil anak Sotoy.

\section{Alusio}

Alusio dalah gaya bahasa yang mengungkapkan sesuatu yang tidak diselesaikan karena sudah dikenal.

$$
\text { Contoh: }
$$

Apakah peristiwa Semanggi bisa terjadi lagi disini?

16. Fabel

Fabel adalah gaya bahasa yang berisi cerita singkat yang mengilustrasikan tumbuh-tumbuhan atau binatang-binatang yang berlaku sebagai manusia. Contoh:

Semut-semut itu saling bekerja sama untuk membawa pulang makanan besar itu.

\section{Antropomorfisme}

Antropomorfisme adalah gaya bahasa yang menggunakan kata atau bentuk lain yang berhubungan dengan manusia untuk hal yang bukan manusia.

$$
\text { Contoh: }
$$

Lidah-lidah lonceng memukul sunyi.

\subsection{Pendekatan Stilistika}

Stilistika (stylistic) adalah ilmu tentang gaya, sedangkan stil (style) adalah cara-cara yang khas, bagaimana segala sesuatu diungkapkan dengan cara tertentu, sehingga tujuan yang dimaksudkan dapat dicapai secara maksimal.

Menurut Fowler dalam Ratna (2009: 17) stilistika sebagai kualitas ekspresi 
semua teks pada dasarnya menampilkan gaya bahasa. Dengan kalimat lain, stilistikalah yang berhasil mengungkap hakikat dan cara-cara penggunaan bahasa pengarang secara keseluruhan. Sebagai ilmu tentang gaya bahasa, stilistika membahas kekhasan penggunaan bahasa seorang pengarang. Jadi, analisis yang digunakan dalam kajian stilistika adalah analisis aspek gaya dalam karya sastra.

Kajian stilistika digunakan untuk memudahkan menikmati, memahami dan menghayati sistem tanda yang digunakan dalam karya sastra yang berfungsi untuk mengetahui ungkapan ekspresif yang ingin diungkapkan oleh pengarang. Dengan demikian, pendekatan stilistika merupakan pendekatan tentang gaya bahasa dalam teks.

\section{METODE PENELITIAN}

\subsection{Metode dan Jenis Penelitian}

\subsubsection{Metode Penelitian}

Metode yang digunakan dalam penelitian ini adalah metode deskriptif kualitatif. Menurut Bogdan dan Taylor dalam Sujarweni (2014: 2) mendefinisikan metodologi kualitatif sebagai prosedur penelitian yang menghasilkan data deskriptif kata tertulis atau lisan dari orang-orang dan prilaku yang dapat diamati. Sedangkan menurut Moleong (2012: 4) penelitian kualitatif merupakan penelitian yang menggunakan latar alamiah, dengan maksud menafsirkan fenomena yang terjadi dan dilakukan dengan jalan melibatkan berbagai metode yang ada.

Metode deskriptif kualitatif digunakan untuk mendeskripsikan penggunaan gaya bahasa perbandingan yang terdapat dalam kumpulan puisi Ada Berita Apa Hari Ini, Den Sastro? karya Sapardi Djoko Damono. Metode ini diharapkan mampu menghasilkan uraian yang mendalam tentang ucapan, tulisan dan prilaku yang dapat diamati dalam puisi sebagai objek kajian dalam penelitian ini.

\subsubsection{Jenis Penelitian}

Jenis penelitian yang digunakan adalah penelitian kepustakaan. Dikatakan penelitian kepustakaan karena kajian dalam penelitian ini berupa data tertulis dan kegiatan dalam mencari, mengumpulkan, dan mendapatkan data-data yang diperlukan dengan cara menelaah dan menganalisis penggunaan gaya bahasa perbandingan dalam kumpulan puisi Ada Berita Apa Hari Ini, Den Sastro? karya Sapardi Djoko Damono.

\subsection{Data dan Sumber Data Penelitian}

\subsubsection{Data}

Data yang digunakan dalam penelitian ini adalah data tertulis berupa teks puisi sebanyak 12 puisi yaitu puisi Ada Berita Apa Hari Ini, Den Sastro?, Tiga Percakapan Telepon, Panorama, Sajak Tafsir, Padang Pasir, Ada Yang Bernyanyi, Rumput, Sebelum Fajar, Kami Mendengar Nyanyian, Malin Kundang, Surah Penghujan: Ayat 124, dan Perihal Waktu yang memuat gaya bahasa perbandingan dalam kumpulan puisi Ada Berita Apa Hari Ini, Den Sastro? karya Sapardi Djoko Damono.

\subsubsection{Sumber Data}

Sumber data dalam penelitian ini adalah sumber data tertulis dalam kumpulan puisi Ada Berita Apa Hari Ini, Den Sastro? karya Sapardi Djoko Damono yang diterbitkan oleh PT Gramedia Pustaka Utama, Jakarta, cetakan pertama pada Maret 2017, cetakan kedua pada Mei 2017, dan terdiri atas 12 puisi.

\subsection{Teknik Pengumpulan Data}

Pengumpulan data dilakukan dengan teknik baca catat terhadap teks kumpulan puisi Ada Berita Apa Hari Ini, Den Sastro? karya Sapardi Djoko Damono. Teknik baca yang dimaksud adalah membaca secara cermat dan berulang-ulang teks kumpulan puisi Ada Berita Apa Hari Ini, Den Sastro? karya Sapardi Djoko Damono. Sedangkan teknik catat dimaksudkan mencatat baris-baris puisi yang mengandung gaya bahasa perbandingan.

\subsection{Teknik Analisis Data}

Analisis data dalam penelitian ini menggunakan pendekatan stilistika. Pendekatan stilistika yaitu pendekatan yang digunakan untuk mengkaji gaya bahasa perbandingan yang digunakan pengarang dalam kumpulan puisi Ada Berita Apa Hari Ini, Den Sastro? karya Sapardi Djoko Damono.

Adapun langkah-langkah yang dilakukan dalam menganalisis data sebagai berikut: 
a. Membaca teks kumpulan puisi Ada Berita Apa Hari Ini, Den Sastro? karya Sapardi Djoko Damono secara keseluruhan dari awal sampai akhir secara berulang- ulang.

b. Setelah membaca puisi, peneliti mengidentifikasi data mengenai gaya bahasa perbandingan dan diberikan kode.

c. Klasifikasi data, yaitu mengklasifikasi atau mengelompokkan data berdasarkan permasalahan dalam penelitian dalam hal ini adalah data mengenai gaya bahasa perbandingan dalam kumpulan puisi Ada Berita Apa Hari Ini, Den Sastro? karya Sapardi Djoko Damono.

\section{HASIL PENELITIAN DAN}

\section{PEMBAHASAN}

4.1 Sekilas Tentang Penyair Kumpulan Puisi Ada Berita Apa Hari Ini, Den Sastro?

Sapardi Djoko Damono lahir pada tanggal 20 Maret 1940 dan telah menerbitkan sejumlah buku puisi, esai, fiksi, drama asli dan terjemahan, sejak tahun 1969. Buku-bukunya telah diterbitkan Gramedia Pustaka Utama (GPU) diantaranya Hujan Bulan Juni, Melipat Jarak, Babad Batu, Bilang Begini Maksudnya Begitu. Sedangkan enam buku puisinya terbit serentak pada tahun 2017 oleh Gramedia Pustaka Utama (GPU) yaitu Duka-Mu abadi, Ayat-ayat Api, Ada Berita Apa Hari Ini, Den Sastro?, Kolam, Namaku Sita, dan Sutradara Itu Menghapus Dialog Kita.

Penghargaan atas pencapaian selama ini diterimanya dari Freedom Institute tahun (2003), Akademi Jakarta (2012), dan Habibie Award (2016). Disamping itu, ia juga menerima Cultural Award (Australia, 1978), Anugrah Puisi Putera (Malaysia, 1984), dan SEA-WRITE Award (Thailand, 1988).

Sapardi adalah pensiunan Guru Besar UI, dan sampai sekarang masih membimbing S-3 di UI, dan menjadi tenaga tetap di Sekolah Pascasarjana UNDIP.

4.2 Gaya Bahasa Perbandingan dalam Kumpulan Puisi Ada berita apa hari ini, Den Sastro? karya Sapardi Djoko Damono.
4.2.1 Gaya Bahasa Personifikasi dalam Kumpulan Puisi Ada Berita Apa Hari Ini, Den Sastro? karya Sapardi Djoko Damono

Jadi, gaya bahasa personifikasi yang terdapat dalam kumpulan puisi Ada berita apa hari ini, Den Sastro? karya Sapardi Djoko Damono yaitu berjumlah 28 kutipan puisi.

4.2.2 Gaya Bahasa Asosiasi atau Perumpamaan dalam Kumpulan Puisi Ada Berita Apa Hari Ini, Den Sastro? karya Sapardi Djoko Damono.

Jadi, gaya bahasa asosiasi atau perumpamaan yang terdapat dalam kumpulan puisi Ada berita apa hari ini, Den Sastro? karya Sapardi Djoko Damono yaitu berjumlah 7 kutipan puisi.

4.2.3 Gaya Bahasa Metafora dalam Kumpulan Puisi Ada berita apa hari ini, Den Sastro? karya Sapardi Djoko Damono.

Jadi, gaya bahasa metafora yang terdapat dalam kumpulan puisi Ada berita apa hari ini, Den Sastro? karya Sapardi Djoko Damono yaitu berjumlah 9 kutipan puisi.

4.2.4 Gaya Bahasa Simbolik dalam Kumpulan Puisi Ada Berita Apa Hari Ini, Den Sastro? karya Sapardi Djoko Damono.

Jadi, gaya bahasa simbolik yang terdapat dalam kumpulan puisi Ada berita apa hari ini, Den Sastro? karya Sapardi Djoko Damono yaitu berjumlah 6 kutipan puisi.

4.2.5 Gaya Bahasa Simile dalam Kumpulan Puisi Ada Berita Apa Hari Ini, Den Sastro? karya Sapardi Djoko Damono

Jadi, gaya bahasa simile yang terdapat dalam kumpulan puisi Ada berita apa hari ini, Den Sastro? karya Sapardi Djoko Damono yaitu berjumlah 13 kutipan puisi. 


\subsubsection{Gaya Bahasa}

Antropomorfisme dalam

Kumpulan Puisi Ada Berita Apa Hari Ini, Den Sastro? karya Sapardi Djoko

\section{Damono}

Jadi, gaya bahasa antropomorfisme yang terdapat dalam kumpulan puisi $A d a$ berita apa hari ini, Den Sastro? karya Sapardi Djoko Damono yaitu berjumlah 1 kutipan puisi.

\subsection{Peranan Gaya Bahasa \\ Perbandingan dalam \\ Kumpulan Puisi Ada Berita \\ Apa Hari Ini, Den Sastro?}

Gaya bahasa perbandingan sangat berperan penting dalam kumpulan puisi Ada berita apa hari ini, den sastro? karya Sapardi Djoko Damono karena dengan menggunakan gaya bahasa atau bahasa kiasan maka puisi tersebut mempunyai sisi keindahan sehingga sajak dalam puisi tersebut menarik untuk dibaca. Setiap pengarang biasanya mempunyai gaya bahasa sendiri, hal ini sesuai dengan sifat dan kegemaran masing-masing pengarang.

\subsection{Pembahasan}

Dalam kumpulan puisi Ada berita apa hari ini, Den Sastro? karya Sapardi Djoko Damono terdapat 6 jenis gaya bahasa perbandingan yaitu gaya bahasa personifikasi, gaya bahasa asosiasi atau perumpamaan, gaya bahasa metafora, gaya bahasa simbolik, gaya bahasa simile dan gaya bahasa antropomorfisme .

Gaya bahasa yang paling dominan dalam kumpulan puisi Ada berita apa hari ini, Den Sastro? karya Sapardi Djoko Damono adalah gaya bahasa personifikasi dengan jumlah 28 kutipan puisi. Gaya bahasa personifikasi lebih dominan karena penulis dalam menuliskan puisinya lebih menekankan pada benda-benda mati atau sesuatu yang tidak bernyawa tetapi seolaholah hidup dan mempunyai sifat layaknya manusia yang bertujuan untuk memikat hati pembaca dan membuat puisi lebih hidup dan menarik untuk dibaca. Gaya bahasa perbandingan dalam kumpulan puisi Ada berita apa hari ini, Den Sastro? karya Sapardi Djoko Damono sangat berperan penting untuk memperindah sajak dalam puisi.

\section{PENUTUP}

5.1 Kesimpulan

Dari hasil pembahasan penelitian yang telah diuraikan pada bagian sebelumnya, maka dapat ditarik kesimpulan tentang gaya bahasa perbandingan dalam kumpulan puisi Ada Berita Apa Hari ini Den Sastro? (Tinjauan Stilistika) karya Sapardi Djoko Damono bahwa terdapat 6 jenis gaya bahasa perbandingan yaitu gaya bahasa Personifikasi, Asosiasi, Metafora, Simbolik, Simile, dan Antropomorfisme. Dalam kumpulan puisi Ada Berita Apa Hari ini Den Sastro? karya Sapardi Djoko Damono, terdapat 28 gaya bahasa Personifikasi, 7 gaya bahasa Asosiasi atau Perumpamaan, 9 gaya bahasa Metafora, 6 gaya bahasa Simbolik, 13 gaya bahasa Simile, dan 1 gaya bahasa Antropomorfisme.

Gaya bahasa yang paling dominan dalam kumpulan puisi Ada berita apa hari ini, Den Sastro? karya Sapardi Djoko Damono adalah gaya bahasa personifikasi dengan jumlah 28 kutipan puisi. Gaya bahasa personifikasi lebih dominan karena penulis dalam menuliskan puisinya lebih menekankan pada bendabenda mati atau sesuatu yang tidak bernyawa seolah-olah hidup dan mempunyai sifat layaknya manusia yang bertujuan untuk memikat hati pembacanya. Selain itu, gaya bahasa perbandingan juga sangat berperan penting dalam kumpulan puisi Ada berita apa hari ini, den sastro? karya Sapardi Djoko Damono karena dengan menggunakan gaya bahasa atau bahasa kiasan maka puisi tersebut mempunyai sisi keindahan yang menarik untuk dibaca.

\subsection{Saran}

Berdasarkan kesimpulan tersebut, dapat dikemukakan beberapa saran sebagai berikut:

1. Penelitian ini dapat dijadikan acuan atau referensi untuk penelitianpenelitian selanjutnya, karena penelitian ini hanya membahas gaya bahasa perbandingan dalam kumpulan puisi Ada Berita Apa Hari ini Den Sastro? (Tinjauan Stilistika) karya Sapardi Djoko Damono. 
2. Kritikan dan masukan yang membangun dari pembaca sangat diharapkan dalam penelitian ini.

\section{DAFTAR PUSTAKA}

Achmad, Sri Wintala. 2015. Buku Induk Mahir dan Sastra Indonesia Pedoman Praktis Menulis dalam Bahasa Indonesia. Yogyakarta: Araska.

Atmanegara, Weda Sasmita. 2018. Pedoman Umum Ejaan Bahasa Indonesia. Yogyakarta: Episentrum Books.

Damono, Sapardi Djoko. 2017. Ada Berita Apa Hari Ini, Den Sastro? Jakarta: PT Gramedia Pustaka Utama.

Haryanta, Agung Tri. 2012. Kamus Kebahasaan dan Kesusastraan. Surakarta: Aksara Sinergi Media.

Hasanuddin, WS. 2002. Membaca dan Menilai Sajak Pengantar Pengkajian dan Interpretasi. Bandung: Angkasa Bandung.

Masruchin, Ulin Nuha. 2017. Buku Pintar Majas, Pantun, dan Puisi. Yogyakarta: Huta Publisher.

Moleong, Lexy J. 2012. Metodologi Penelitian Kualitatif Edisi Revisi. Bandung: PT Remaja Rosdakarya.

Mulyadi, Yadi. 2017. Bahasa dan Sastra Indonesia untuk Siswa SMA/MA Kelas XII Kelompok Peminatan Ilmu-ilmu Bahasa dan Budaya. Bandung: Yrama Widya.

Pradopo. Rachmat Djoko. 2017. Pengkajian Puisi. Yogyakarta: Gadjah Mada University Press.

Ratna, Nyoman Kutha. 2009. Stilistika Kajian Puitika Bahasa, Sastra, dan Budaya. Yogyakarta: Pustaka Pelajar.

Soenaryo, Andi. 2002. Buku Pintar Pantun dan Puisi. Jakarta: Kartika.

Sugono, Dendy. 2011. Buku Praktis Bahasa Indonesia Jilid 1. Jakarta: Kementerian Pendidikan Kebudayaaan.

Sujarweni, V. Wiratna. 2014. Metodologi Penelitian. Yogyakarta: Pustakabarupress.

Trianto, Agus. 2006. Pasti Bisa Pembahasan Tuntas Kompetensi Bahasa Indonesia untuk SMP dan MTs Kelas VIII. Jakarta: Erlangga.

Wahyudi, Johan 2009. Bahasaku Bahasa Indonesia 2 untuk Kelas VIII SMP dan MTs. Jakarta: PT Tiga Serangkai Pustaka Mandiri.
Wahyuni, Ristri. 2014. Kitab Lengkap Puisi, Prosa, dan Pantun Lama. Jakarta Selatan: Saufa 